\section{NEW MUSEUM AND LABORATORIES OF ZOOLOGY AT LIVERPOOL.}

THE new museum and laboratories of zoology of the University of Liverpool were opened on Saturday last, November 18, by the Earl of Onslow, formerly President of the Board of Agriculture and Fisheries, and now chairman of committees of the House of Lords.

The history of the department of zoology at Liverpool and the character of the new buildings are described in a pamphlet issued by the university, and abridged at the end of this record of the opening ceremony.

Preparatory to the actual ceremony of inauguration at tre new building, there was a large gathering in the arts theatre of the university of guests of the ccuncil and senate of the university. Apologies and letters of regret for unavoidable absence were received from the president of the Royal Society, Sir Archibald Geikie, Prof. Ray Lankester, Sir Henry Roscoe, and many other men of science. A resolution passed at the meeting of the Linnean Society of London on November 16 , signed by the officers, and congratulating the University of Liverpool and their president (Prof. Herdman) on the new laboratories, was received.

Dr. Nansen had accepted the invitation and hoped to be present, but at the last sent his regrets and a telegram saying:" Hearty congratulations to the Zoological Department of the University of Liverpool.--NANSEN.'

Lord Onslow was introduced to the assembly by the Chancellor, the Earl of Derby ; and in the course of his remarks he is reported by the Liverpool Daily Post and Mercury to have spoken as follows :-

LORD ONS_OW ON SCIENCE ANd the State.

In the first place he wished to congratulate the University of Liverpool on their decision to set apart a sum sufficient properly to equip the museum and laboratories of the natural history and zoological department of the university. $\mathrm{He}$ thought that was a wise step, but it was a step which could only have been accomplished, in common with all the rest of the work of the university, by the great liberality of the captains of industry in Liverpool, who had realised that the application of science to commerce was one of the most important things for commerce itself. When he looked back on the list of benefactors to the Liverpool University, he found the names of Brunner, Holt, Tate, Johnston, Rathbone, and others, and he was struck by the fact that in Liverpool at any rate the application of science to commerce was thoroughly appreciated. Although there was in this country a great amount of private wealth and of private benefaction, he was afraid it must be confessed that the amount which had been devoted to the promotion of university education "pales its ineffectual fires " before what had been done in America. In the United States of America as much as $7,000,000 l$. had been bequeathed or given in two years to the purposes of university education. What was the reason for that? He thought that in a large measure it was due to the great difference between the United States of America and this country. The difference was that in the United States there were no hereditary honours or titles, and if a man wanted the future generation to have a record of his existence it could only be NO. I 882 , vOL. 73] done by associating his name either with a university or with a chair in that university, or by some other great benefaction. The result was that the United States had rich universities, such as that of Cornell, founded by individuals, and he confessed that if he were a man of great wealth he would much rather posterity would remember him as having founded a university or a chair of a university than as having been a liberal subscriber to the funds of his party. Though a good understanding existed between this country and other Great Powers, provision should be made for the war in commercial supremacy. What were the armaments with which we ware to provide ourselves for the purposes of defence in the war of commercial supremacy? They were those provided by science and by scientific research. Fortunately for us, the inventions of science could not be patented in the interests of any one particular country, but the slightest improvement upon them could, and it was those improvements, arrived at by scientific research, which would make or mar the supremacy of any country in commerce. The power of adding to a train-load that could be carried by a locomotive in the other hemisphere might make a differ- 
of this country upon which the prosperity of the future of the country depended. One of them was the re-organisation of the Army, and the other was the organisation of the education of the country. Both those questions required the expenditure of large sums of money, and he did not believe that under the present system it would be possible to obtain those large sums unless in some manner or another they could see their way to broaden the basis of taxation. When the business of the fisheries of the country was handed over to his (Lord Onslow's) department he naturally expected, as an ignorant Minister did, that he would find the broad lines upon which it was expected that he should shape his policy already laid down by experts and men of science. But instead of that he found a wall of ignorance as regarded evervthing that affected the biological and physical condition of our territorial waters. What they wanted to know was by scientific research whether anything could be done to stem the depopulation of the ocean if that depopulation was actually know how to protect human beings from the danger of eating contaminated shell-fish. They had done much in the Liverpool University for the study of tropical diseases; they had ascertained much to protect the lives of their fellow-subjects who went out to the malarial coasts of West Africa; he sincerely hoped that they would be able also to show them how they could avoid pollution from the contamination of shell-fish. He hoped that all who had worked in the laboratories of the university would be stimulated to greater efforts by the better buildings in which they would be housed.

The Chancellor read a communication received from Sir Thomas Elliott, Permanent Secretary of the Board of Agriculture and Fisheries, intimating that the Board were pleased to award the university a grant of $200 \mathrm{l}$. for the financial year ending March, 1906, in respect of the zoological work carried on in connection with the. fishing industry, and conveying the congratulations of the Board on the completion of the zoological museum and labor-
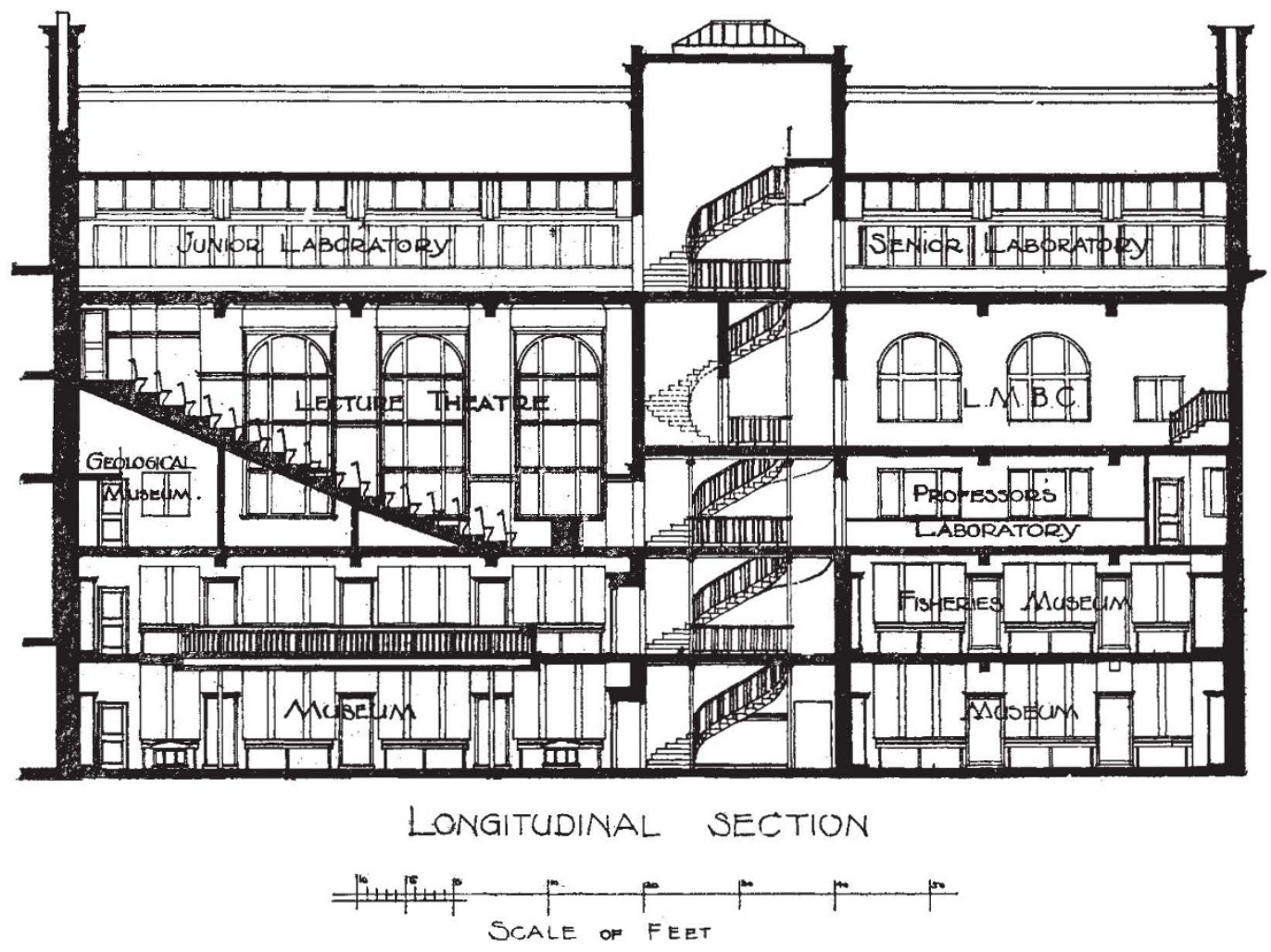

FIG. 2.-New Buildings of the Department of Zoclogy, University of Liverpool.

going on. That work must be divided under two headsstatistical and biological. The statistical work could not, of course, be properly performed by a university such as that. That was a matter which must be taken in hand by the central authority. He looked very largely to the Lancashire Sea Fisheries Committee, acting in conjunction with the University of Liverpool, to pursue the biological part of those inquiries. He was in hopes that when the expenditure of this country upon the international investigation of the North Sea came to a close there might be national funds available for assisting them in the research which they had undertaken for some time past, and which he could not doubt but with the opening of those new buildings would be largely stimulated and increased, and that thereby they might be assisted by them to solve problems which were great and national. There was also the great and important question of the connection of human disease with shell-fish. They wanted to find out to what extent there was contamination in shell-fish, and also what was not dangerous to the human frame. It was really of the very greatest possible importance that they should NO 1882 , vOL. 737 atories, which they hoped would be of service "both in the advancement of scientific knowledge and in the solution of many problems of importance to the fishing industry." Sir Thomas Elliott afterwards spoke.

Replying to a vote of thanks moved by Mr. E. K. Muspratt and seconded by Sir John Brunner, M.P., Lord Onslow said he was not by any means alone in his appreciation of not only the benefit, but the absolute necessity of all Government departments in their respective spheres availing themselves of the advantages of scientific research. It applied not only to Government departments, but equally to all the great industries, to the Navy and the Army, and to every branch of national enterprise. In regretting that the 2ool. contribution to which Sir Thomas Elliott had referred was regarded as small, Lord Onslow said it was not the Board of Agriculture who was rich, it was the Chancellor of the Exchequer, and when they got a few thousands out of the Chancellor of the Exchequer for all the purposes of agriculture and fisheries, they thought they had done very well when they were able to contribute $200 l$. to one place. 
The proceedings in the arts theatre then ended, and Lord Onslow and the council and senate and guests walked through the university grounds to the new zoology buildings, where, after a short speech by Prof. Herdman, Sir John Murray addressed the assembly upon oceanography. Mr. R. B. Haldane also delivered a brief speech, in the course of which he remarked that by obtaining the grant of $200 l$. from the Chancellor of the Exchequer Sir Thomas Elliott had established a principle and connected the University of Liverpool with His Majesty's Government.

The Department of Zoology.

The Derby chair of natural history was established by the fifteenth Earl of Derby in $188 \mathrm{I}$-an appropriate gift from a descendant of the scientific founder ${ }^{1}$ of the celebrated zoological collections once alive at Knowsley and now secured to Liverpool in the Derby Museum of the Public Galleries. The first Derby professor was appointed at the end of $I 88 \mathrm{r}$, and thus natural history was one of the three or four scientific departments with which University College opened in January, 1882 . The work of the Liverpool Marine Biology Committee has been so intimately bound up with the Natural History Department during the last twenty years that, although not, strictly speaking, a part of the university organisation, it is impossible to omit a brief record of its history. Established for the purpose of exploring the fauna and flora of Liverpool Bay and the neighbouring parts of the Irish Sea, it brought a number of the local field-naturalists into close relation with the university department and laboratory methods, it gave rise to dredging expeditions and observations and experiments at sea, which led on in later years to sea-fisheries investigations, and it resulted in the accumulation of collections which have proved of considerable interest and scientific value. The "local" collection in the museum of the new buildings has been almost wholly obtained through the work of the L.M.B.C.

Probably the most important outcome of this exploring work has been the establishment of a marine biological station on the west coast of England. After five years' use of an old Dock Board observatory on Puffin Island, off Anglesey, the committee moved their marine station to Port Erin, at the south end of the Isle of Man, where they have now a substantial, new, two-storeyed building, measuring 95 feet by 45 feet, containing laboratories, an aquarium, and a fish-hatchery, and provided with a large, open-air, sea-water pond for the spawning and rearing of fish. As to the results obtained from this institution (which is under the direction of the Derby professor, and is worked in connection with the university department), it will suffice to state that during the last year thirty-six investigators worked in the laboratory, about five millions of young plaice were sent out to sea from the fish-hatchery, and more than thirteen thousand visitors paid for admission to the aquarium.

It was certainly to this marine biological work in the past that the natural history department owed in the first instance that connection with the local sea-fisheries authorities which has recently developed into a formal agreement between the university and the Lancashire and Western Sea Fisheries Committee. The scientific work of the local fisheries district is carried on in the laboratories by assistants paid by the Fisheries Committee, and the professor has been appointed honorary director of the scientific work, and furnishes an annual report on the work of the fisheries laboratory. A share of the laboratory accommodation in the new buildings will be devoted to the furtherance of the work of the Liverpool Marine Biology Committee, of the Lancashire and Western Sea Fisheries Committee, of economic entomology, and of other useful applications of zoology.

It has been recognised for some years that the accommodation in the old college buildings was quite inadequate to meet the wants of this department, and although some extensions had been made, such as a wooden fisheries laboratory on the roof and a convenient little museum (given about ten years ago by the late Mr. George Holt), these were temporary expedients which in some ways only emphasised the pressing need for new and much larger

1 The thirteenth Farl of Derby, President of the I innean Society, 1828I8?3, and subsequently President of the Zoological Society. buildings. Research work offered to the department was hampered, and in some cases had to be declined for want of room. These facts were given expression to in the statements of needs drawn up in connection with the university movement of Igor-2, and after the establishment of the university a sum of $18,000 l$. was voted to the council by the university committee in October, 1902, for the purpose of erecting and equipping a new department of zoology, to contain a museum and a lecture theatre, the necessary students' laboratories, and also accommodation for sea fisheries investigations and other lines of marine biological research.

\section{The New Buldings.}

This zoological institute has a frontage of 123 feet on the western side of Brownlow Street, is $4 \mathrm{I}$ feet from fron to back, and 84 feet in height from the street level. It is built of red pressed brick relieved with white sandstone from the Storeton quarries in Cheshire. The building consists of a central tower containing the entrance hall and staircase and some of the smaller rooms on each floor, and of two blocks, the north and the south, which have been treated rather differently as regards internal structure. The south block has only three main floors, while the north has five in the same height. The central tower extends a storey higher. In the south block the three floors accommodate (I) the museum with its large gallery; (2) the lecture theatre; and (3) the large junior laboratory at the top of the building. In the north block, on the two lower floors there are extensions of the museum to receive special collections, and the rest of the space is devoted to the senior class-room, senior and honours students' laboratories, the departmental library, and rather large laboratory and store-room accommodation for the sea fisheries department, the work of the economic entomologist, of the marine biological committee, and other practical applications of zoology. In the central tower, along with the staircase, there are small rooms for the professor and two demonstrators, the laboratory assistant, with diagram, chemical, aquarium, photographic, macerating rooms and students' lavatories.

GEOLOGY AT THE BRITISH ASSOCIATION

I $\mathrm{N}$ Section $\mathrm{C}$ the papers read were largely on subjects of local interest, and in many cases by South African geologists. The delivery of the presidential address in this section having been fixed for the meeting at Johannesburg, the proceedings at Cape Town were opened with a short address of introduction by the president, followed by a lecture by $\mathrm{Mr}$. A. W. Rogers, the director of the Colonial Geological Survey, on the outlines of the geology of the Cape Colony.

Among the subjects discussed, the Karroo claimed a considerable share of attention. Prof. R. Broom, in a paper on the classification of the Karroo beds, retained the division into Dwyka, Ecca, Beaufort, and Stormberg series. He subdivides the Beaufort series into three, and the Stormberg into two parts on reptile evidence, and correlates the various divisions with European strata thus:-Dwyka and Ecca series with Lower and Middle Permian, Lower Beaufort beds with Upper Permian, Middle and Upper Beaufort beds with Lower and Upper Trias, Lower Stormberg beds with Rhætic, and Upper Stormberg beds with Lower Jurassic.

Mr. A. L. du Toit gave an account of the Stormberg formation in Cape Colony. This uppermost division of the Karroo beds consists of a considerable thickness of nearly horizontal sandstones, shales, and volcanic rocks, and includes (in descending order):-(4) Volcanic Beds; (3) Cave Sandstone; (2) Red Beds; (1) Molteno Beds. The formation covers a considerable area in the east of the colony, in the Stormberg and Drakensberg districts, the summits of the mountains being commonly formed of the lava flows of (4). The sediments were deposited in an inland sea, the "Karroo Lake," the southern shore-line of which ran along the present coast-ranges of the colony, and thence north-eastward, outside and parallel with the coast-line of Natal. The author suggests the correlation of the Volcanic Beds and Cave Sandstone with the Rájmahál series of India (Middle? and Lower Jurassic), and of the Molteno beds with the Kota-Maleri series of India and the Wianamatta series of New South Wales (Rhætic). 